Anna Fiń

Institute of Philosophy and Sociology Pedagogical University of Krakow, Poland

\title{
Between Neighbors - Between Immigrants \\ Poles and Ukrainians in the United States During the Time of the Cold War: A Few Reflections
}

This article deals with the problem of ethnic relations between Polish and Ukrainian immigrants in the United States between the years 1945-1991 by way of a sociological interpretation of the historical process. The author describes two basic forms of intergroup behavior including conflict relations (factors triggering conflict) and intergroup cooperation. The paper therefore tries to reveal the correlation between what "has happened" between members of the groups in European conditions and how this impacts intergroup relations in the diaspora.

Key words: ethnic relations, "displaced borderland," Polish and Ukrainian emigrations in the U.S., Polish-Ukrainian relations in the U.S., political emigrations

\section{Introduction}

Although the representatives of social science seem to agree that "sociology of ethnicity is not equivalent to sociology of migration" (Fenton 148), one writing about migration cannot omit the issue of ethnic intergroup relations, actually being a consequence or a result of a complex and widely understood migration process. When following the proceedings of the subject literature, in particular in the U.S., we can observe that the prevailing majority of research conducted in this scope has been related to racial relations, as well as to relations between the dominant group and the minorities. The issue of relations between the immigrant groups, in particular those of European origin, was only mentioned at the occasion of discussing other issues (e.g. transformations of the ethnic community or ethnic mobilization). ${ }^{1}$ In the context

1 The issue has been described more detailed by historians. The example is the works of Anna Mazurkiewicz devoted to the problem of political emigration of Europeans in the United States. See more: Uchodźcy polityczni z Europy Środkowo-Wschodniej w amerykańskiej polityce zimnowojennej, 1948-1954 (chapter III and IV); "Relationship between the Assembly of Captive European Nations and the Free Europe Committee in 1950-1960," 91-130; "Join, or Die' - The 
of such a gap in the subject literature, the question of intergroup relations constituted by common European cultural and national heritage becomes particularly important. This paper is an attempt to describe this phenomenon. It deals with the issue of relations between Polish and Ukrainian immigrants in the American society. In the paper I do not make the attempt to describe the entire scope of these relationships ${ }^{2}$ but only focus on a selected historical period between 1945 and 1989, i.e. in the so called Cold War period. Therefore, the main contexts of the present considerations are the events of a historical nature. Being subject to interpretation, they show the specific nature of relations between the Polish and Ukrainian political emigration. This is so important since the literature, both historical and sociological, is lacking elaborations dedicated to relations between European immigrant groups it this period. This refers in particular to groups of Central and Eastern European origin.

In the common understanding, the neighborhood of the Poles and the Ukrainians refers to the political and cultural neighborhood of two nations in Europe and, in the context of the discussed period, is sometimes described as a "difficult" neighborhood, marked with multiple ethnic conflicts (Stępień; Wojakowski). Therefore, the following questions arise: how do the certain processes going on within great structures, characteristic both to the European and American society, influence the relations between the researched groups in the diaspora situation? Did the collectivities of political emigrants indeed transfer the conflicts which had arisen in European conditions into emigration conditions? If yes then which? Can we discuss here only a conflict of political interests? What was the real nature of these relations? How were the mutual relations in the diaspora impacted by the cultural closeness of both collectivities and the long-lasting neighbor traditions in Europe? Answering the above questions is the main objective of the present text.

The empirical context for these considerations is the research conducted by me in the years 2006-2009 within the "Poles and Ukrainians in American Pluralistic Society" project. ${ }^{3}$ The presented considerations are, on the one hand, the outcome of interviews with members of the Polish and Ukrainian diaspora in the U.S. and, on the other, the result of the analysis of available data, in particular archive documents and press articles, ${ }^{4}$ constituting the key source of empirical material used in this paper.

Road to Cooperation Among East European Exiled Political Leaders in the United States, 1949-1954," 5-43.

2 This issue has been widely described in: Fiń, Anna. "In the space of displaced borderland. A few reflections on the relationships between Polish and Ukrainian immigrants in the United States," Studia Migracyjne - Przeglad Polonijny. No. 1, 2014: 143-161.

3 The project was carried out by the Author in the years 2007-2009 and financed by the Kosciuszko Foundation Research Grant and the Shevchenko Scientific Society Grant. This paper is a kind of explanation and supplementation of considerations on Ukrainian emigration and the activity of the Ukrainian diaspora in the United States in the Cold War period, i.e. in the years 1945-1990. It is a part of an international research project entitled "Cold War Emigration form East Central Europe - General Historical Survey," which is a part of a large-scale project entitled: "Polish Political Emigration: 1939-1990," conducted by The Institute of National Remembrance in Poland. The result of the project will be published in the form of book.

4 The empirical material was collected from the following institutions: the Polish Institute of Arts and Science; the Shevchenko Scientific Society; New York Public Library; the 


\section{From the concept of ethnic relations to the term of "displaced borderland": a theoretical framework}

The discussed issue needs to be at least briefly described from a theoretical point of view, as otherwise the specific nature of relations between the Polish and the Ukrainian diaspora would be difficult to present. The basic context for these considerations is the concept of ethnic relations. The theories of ethnic relations developed starting from pioneer studies of representatives of the Chicago school and from Emory Bogardus research on racial relations and the perception of social distance. From that time on many concepts, distinctions and typologies have been elaborated within the space of social science in order to explain the phenomenon of ethnic relations. These positions usually reduced the substance of ethnic relations to the entirety of relations between various ethnicities: usually between an ethnic minority and the dominant group or the society as the whole. Frequently, these relations were referred to as: cultural contacts, interethnic cohabitation, ethnic interaction or ethnic meetings. In spite of the presence of multiple approaches, one thing seemed to be a subject of common consent: that the phenomenon of ethnic relations derives from the existence of cultural differences between the groups and from appearance of various forms of contacts between the members of various ethnic groups. Starting from such an approach, scientists have managed, over many years, to establish a certain paradigm of analysis of ethnic relations. It is comprised of three, very popular theoretical concepts: those of assimilation, amalgamation (the melting pot model) and cultural pluralism (accommodation). Moreover, based on the conducted literature review, it can be stated that the differences between the researchers related to defining the ethnic relations come down to two, general models: the conflict and the integrationist one.

Nevertheless, a detailed presentation of all these concepts and theoretical traditions would significantly exceed the frames of this elaboration. Therefore, I claim that relations between European immigrant groups shall be described based on broader and more differentiated theoretical assumptions. It means that when analyzing them, one shall exceed the existing paradigm. An approach enabling such a move is considering the ethnic relations as a certain type of social relations. ${ }^{5}$ Such a way of conceptualizing ethnic relations was already represented in American sociology in the 1950s by Edward C. McDonagh (11), while in Polish sociology by Janusz Mucha, inspired by the works of Florian Znaniecki, macro-sociology of Peter M. Blau and the theory of minority relations of Hubert M. Blalock. This author suggests, among others, to analyze, within social research, "not only various phenomena occurring within particular ethnic groups" but "for many reasons it is worth researching what

Immigration History Research Center of University of Minnesota; the Library of Columbia University, the Pilsudski Institute of America, The Polish Veterans Army Association in New York City; The Ukrainian American Coordinating Council, St. George Ukrainian Catholic Church in New York; Hoover Institution Archive, Stanford University. Moreover, the Author also refers to the in-depth interviews she performed with the members of Ukrainian diaspora in New York.

5 In the social sciences, the social relation is referred to as relatively permanent and normalized interactions (relations, impacts, dependencies) between members of various social groups and the groups themselves. (Sztompka 89-94). 
is happening between them: between particular people, being members of various ethnic groups, and between these groups, hypothetically perceived as social integrities" (Mucha 261). Ethnic relations understood as social relations include a vast richness of forms of mutual references and interactions. These may include: mutual help, dialogue, conflict, competition, collaboration between institutions and states, superficial and loose acquaintances as well as deep relations of friendship and marriage. From the point of view of this approach, ethnic relations, just as social relations, may take place in various spheres and areas of social life, may be of a various nature, intensity, durability and intimacy, various levels of formalization and institutionalization. A description of ethnic relations perceived in such a way, apart from an analysis of the psycho-sociologist effect (i.e. the dimension of relationships attitudes and distances) shall also include structural conditions (i.e. all phenomena facilitating or limiting the possibilities of making and keeping certain relations).

Adopting such a way of understanding ethnic relations enables distinguishing other notions and phenomena, helpful is explaining the nature of relations between certain immigrant groups. In the case of Poles and Ukrainians in the U.S., such a conceptual category is the notion of a "displaced borderland." This concept is based on the assumption that contacts and relations between these groups in the American society are very often determined not only by the situation of both collectivities in the diaspora but also by these groups' European experience and heritage. It also stipulates that these relations, as the relations in Europe, are multilevel and multi-dimensional, as is typical of an ethnic borderland situation, where an interchange of cultures and societies always takes place. When describing mutual relations, this concept enables taking three basic levels of the analysis into account: (a) macrostructural (e.g. historical background, political factors, place of the groups in the stratification system of the adopting society, spatial relations); (b) mezzo-structural (impact of institutions) and (c) micro-structural (psychical relations, attitudes, stereotypes and distances).

In this paper I focus only on selected aspects, enabling the dependence between "what happened" in the Polish-Ukrainian borderland and the intergroup relations in the diaspora to be captured, and to formulate general conclusions on various forms of intergroup influence. In this text I refer mainly to the institutional level of relations.

\section{The main aspects of the relationships between Polish and Ukrainian immigrants in the United States during the Cold War}

The history of Polish-Ukrainian relations in the U.S. dates back to the beginning of history for both these groups in American society. Since the beginning, the relations have been conducted on multiple dimensions. The most important are following dimensions,: a) migratory process itself (we can speak about a chain migration of these two ethnic groups; mutual imitation of migratory behaviors; similarity of the social position etc.); b) spatial relations and common neighborhood in the diaspora (similarity of settlements patterns); c) the daily life of immigrants (for example: shared use of ethnic institutions; cases of joint celebrations of holidays; similarity of 
language; mixed marriages, relations on a professional level, social and friendly relationships etc.) and d) relations between ethnic institutions (Fiń).

Between 1945-1989, Poland and Ukraine were under Soviet influence and they had no possibility of creating mutual relations. The entire period was characterized by the "freezing" of Polish-Ukrainian relations in Europe: there were no relations on a national level, personal relations between groups were limited, mutual aversion and a feeling of injustice created by war remained. The place where the tensions arose was mostly the Polish-Ukrainian borderland. Immediately after World War II, the relations between Poles and Ukrainians were impacted by: anti-Polish struggle of the Ukrainian Insurgent Army in the south-east of Poland, deportations conducted within the so called Vistula Operation and the decision made in 1947 to settle the Ukrainian population in the concentration camp in Jaworzno. ${ }^{6}$ In the latter years, the escalation of mutual reluctance was fostered by anti-Ukrainian propaganda of the communist Polish government and the assimilation policy it conducted. The actions of the communist state resulted in the liquidation of organized forms of Ukrainian minority in Poland, thus contributing to the annihilation of multicultural forms of living on the borderland.

The Polish-Ukrainian relations in the diaspora were of a completely different nature. It is estimated that in the years 1945-1990, about 390 thousand Poles (Rokicki 48-49; "Immigrants by Country of Birth: 1961-2005"; Yearbook of Immigration Statistics 2005) ${ }^{7}$ and around 120 thousand Ukrainians (Lencyk Pawliczko 92; Wolowyna) settled in the United States. Taking the overall nature of Polish and Ukrainian emigration in the Cold War era into account, one shall state that intergroup relations in the diaspora were generally created by Displaced Persons (DP's) and political refugees. These relations were multifaceted and very much differentiated. Based on an analysis of archive documents and press publications, one can distinguish at least several spheres of these relations: the first one, of the most conflict-triggering nature, was focused on the borders, the situation of the Ukrainian minority in Poland, as well as stereotypes and negative attitudes brought to the diaspora. The further ones were related to the attempts for dialogue and cooperation, both in a political and scientific-cultural scope. Let us take a closer look at them:

\section{Conflict relations/factors triggering conflict}

Conflicts and intergroup disagreements which exist in the American society have been transplanted from Europe into the diaspora. This means that they have their

6 The "Vistula Operation" is the name of the 1947 campaign of the deportation of the population of Ukrainian origin from south-east Poland to the so called Regained Lands. The decision on the deportation was taken by the Polish communist government within the struggle with the Ukrainian national movement active in Poland. In practice, this operation did not only include the UPA (Ukrainian Insurgent Army) combatants, but the entire Ukrainian population (Misiło).

7 One shall obviously take into account that these figures are of only an approximate nature. They do not reflect the actual scale of Polish emigration since they do not cover illegal emigrants. It is estimated that between 1965 and 1990, 957,360 persons from Poland arrived to the U.S. declaring a temporary stay for tourist purposes but actually searching for jobs (Blejwas 93). 
roots in the old country and internal American factors had no impact on them. The following factors were the main reasons for conflicts between Polish and Ukrainian immigrants: a) conflicts of political interests; b) negative attitudes and stereotypes brought over from Europe; as well as c) conflicts over significant group values (e.g. tensions around the interpretation of common history). The conflicting nature of the intergroup relations was caused firstly by the issue of the Eastern border. The conflict was caused by the different territorial postulates. As a result of the decisions made in Yalta in 1945, the Eastern Polish lands were attached to the Soviet Union. The new Polish border separated, from Poland, lands that, according to Poles' awareness (especially those who as a result of war became emigrants) were inherently Polish. At the same time, Soviet Ukraine did not gain Subkarpathia, Chełm Lands and parts of Lesser Poland: for years they were disputed territories, which Ukraine perceived as "Ukrainian ethnographic territory." The Polish group tried to abolish the decision made in Yalta. It organized an active lobby in the American government; published its opinions in ethnic newspapers, resolutions and many memorials. For instance, during the $2^{\text {nd }}$ Convent of the Polish American Congress (KPA) held in May 1949, KPA president Karol Rozmarek claimed: "We have gathered here in favor of the care of the independence of Poland with Eastern border as of 1939, with the current Western border on the Odra and Nysa rivers - the care of Poland with Lviv, Vilnius, Gdansk and Szczecin" (Kardela 11). The same ideas were expressed in special resolutions adopted by the KPA in 1956 in Philadelphia and Buffalo, in 1957 in New York and in 1960 in Chicago. In each of them it was emphasized that "The Polish American Congress will not stop its efforts to restore the Polish borders from before" ("UCCA Scores Imperialics..." 3). These activities were controversial for Ukrainian immigrants', especially since at that time the core of the emigration was made up of emigrants from the Polish-Ukrainian borderland. Both the ethnic press and special declarations opposed against the actions of Polish emigrants, usually referring to them as "imperialistic aspirations of Polish emigration group." 8 To better understand the scale of this problem, one can quote the fragments of declarations published by representatives of the Ukrainian diaspora, stating that: "The Polish press still talks about old memories of "Polish Lviv," "Polish Vilnius," although Polish Vilnius and Polish Lviv are long gone" ("Przegląd Prasy Ukraińskiej." Polish Embassy in the U.S.), "all current activities of Polish emigration aimed against Curzon line as the future Polish-Ukrainian national border contradict natural law and principles of politics established and approved by the United States (...) Russian imperialism cannot be defeated with propaganda of Polish imperialism" ("Declaration of the Ukrainian Congress Committee of America" 2). The presented opinions clearly point at the contradiction between the Ukrainian and Polish group's interests, as Ukrainian emigration politicians claimed that the Eastern territories of the former Republic of Poland were indisputably a part of Ukraine. The representatives of the Polish diaspora, on the other hand, subsequently raised the thesis of these lands' belonging to the Polish state. Therefore, Ukrainian press and books issued in the U.S. discussed the "colonization of ethnographic territory," and Lviv and Przemyśl were

8 See: "Polish-Ukrainian Relations Today." The Ukrainian Quarterly. No. 2, 1948: 108; "Declaration of the Ukrainian Congress Committee of America on the Matter of UkrainianPolish Relations." The Ukrainian Bulletin, 1-15 June 1957: 2. 
described as "Western bastions of Ukraine" ("The Yalta Agreement..." 236; "Ukrainian-Polish Relation..." 348; Zahajkewycz). An analogical valorization of this area was present in Polish emigrants' publications, so their Polish nature was emphasized and Lviv itself was described as a "Polish stronghold." ${ }^{9}$ The maps, reflecting the territorial postulates of both immigrant groups are also an indicator of the presence of the mentioned attitudes (see Figure 1). ${ }^{10}$

The differences in perception of the question of the Eastern border disturbed the process of intergroup communication, and mutual tensions were so strong that at the turn of 1960's and 1970's, the Czech-Polish-Ukrainian Society in Chicago stopped its activities. ${ }^{11}$ Also the reports of ethnic organizations found the issue of the right to the borderland the key element antagonizing the members of the Polish and Ukrainian diasporas. ${ }^{12}$ The conflict decreased only in the mid 1970's and the attempts to acknowledge the status quo in the matters of Polish borders, ${ }^{13}$ met with a very positive reaction of the Ukrainian immigration and were described in the ethnic press as: "the most sincere, honest (...) logical and practical approach" ("For a Double Understanding..." 235).

Other controversial issues concerned such problems as: a) the poor situation of the Ukrainian minority in the Polish People's Republic, connected with the so called Operation Vistula conducted in 1947 and the assimilation policy of the communist government; b) the poor situation of the Polish minority in Soviet Ukraine; c) the continuous devastation of the Cemetery of Eaglets in Lviv. Already in 1946, the Ukrainian diaspora in the U.S. started arranging protests against the actions of the Polish

9 As an example, one can take the series of articles of Józefa Mękarska „Wędrówka po ziemiach wschodnich Rzeczypospolitej", published in the years 1982-1983 in the magazine Kombatant w Ameryce, see: No. 2, 1982: 15-18; No. 3, 1982: 17-19; No. 1, 1983: 18-10; No. 4, 1983: 16-18.

10 In the case of the Ukrainian diaspora, the map of ethnic Ukraine can be found in: Walter Dushnyck, Recognition of Ukrainian in the U.S. Census. The Ukrainian Congress Committee of America, 1960, Imigration History Research Center Archive, Collection No. 10; and also in the book of Bohdan Zahajkewycz (Zahajkewycz 128-129); Polish territorial postulates on the other hand can be found in Kombatant w Ameryce.

11 Information obtained through the analysis of correspondence between Wacław Jędrzejewicz and Stanisław Paprocki, see: "Archiwum Wacława Jędrzejewicza: Korespondencja Wacława Jędrzejewicza ze Stanisławem Paprockim rok 1971.” Józef Piłsudski Archive In New York, No 053, folder 8.

12 In one of them, the President of the Ukrainian Congress Committee of America, Walter Dushnyck wrote: "The problem of western Ukraine is the main obstacle preventing the full integration of both groups" ("Dushnyck, Ukrainian Political Situation Today." IHRC Archive, 160; "Political Currents among Ukrainian Americans." PIASA Archive, 4-5).

13 The North American Study Center for Polish Affairs at that time published a document "Program of the Coalition for Polish Independence," where it was written that: "in spite of losing Lviv and Vilnius, connected to Polish culture for ages, which is and will remain to be infinitely painful, we do not put forward territorial claims against our Eastern neighbors. We demand however (...) that Poles from Poland be guaranteed equal rights, and possibility to defend their native language and culture. We also demand that Poles from Poland have unlimited access to places connected to the history of both our nations" see: "For a Double Understanding between Ukraine and its Neighbors," The Ukrainian Quarterly. No. 3, 1977: 234-235. 
Figure 1. Territorial postulates of the Polish and Ukrainian diasporas 1945-1989

ETHNOGRAPHIC TERRITORY OF UKRAINE
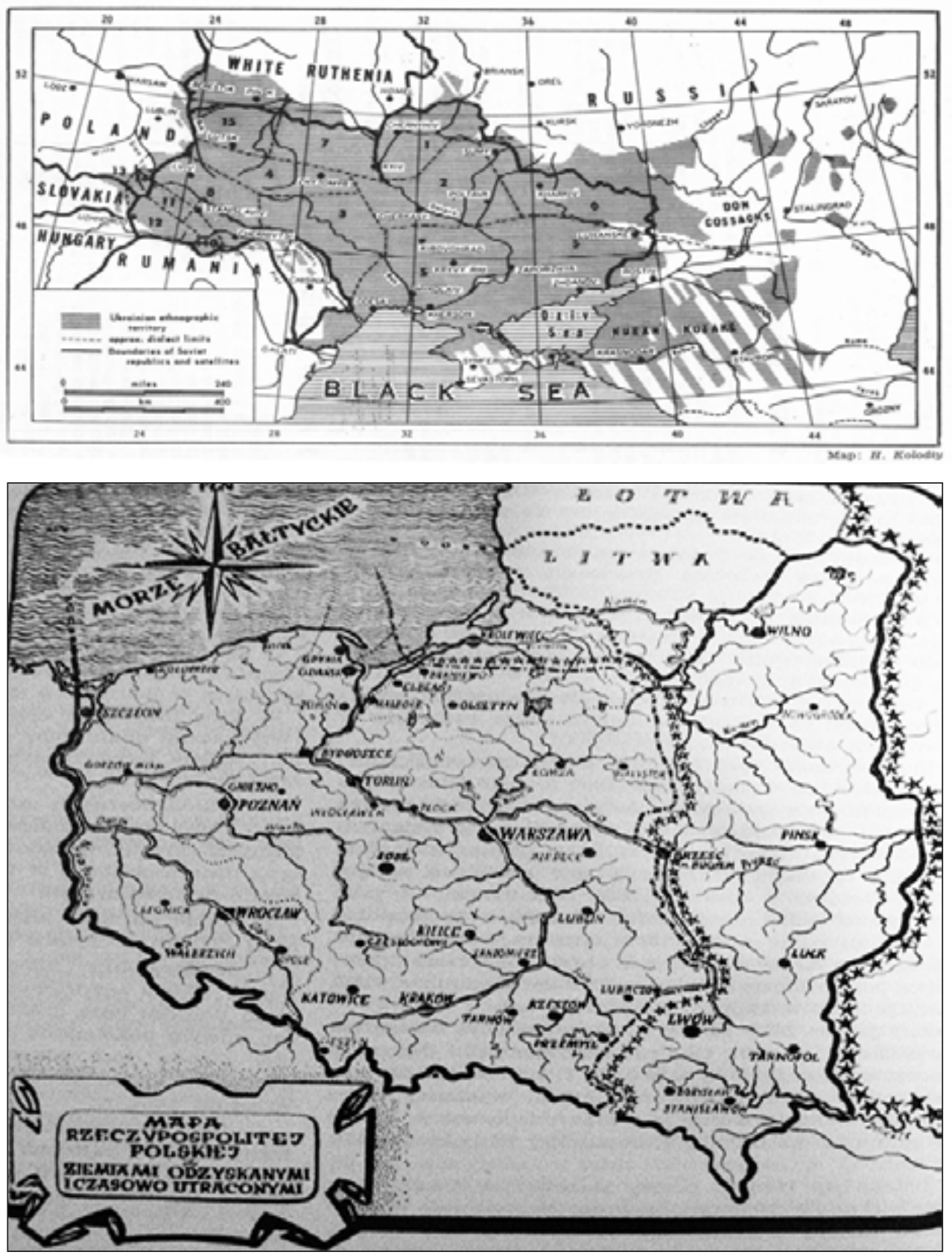

Source: Dushnyck, Walter, “Recognition of Ukrainian in the U.S. Census, The Ukrainian Congress Committee of America, 1960." Immigration History Research Center Archive, Collection No. 10; and Mękarska, Józefa, "Wędrówka po ziemiach wschodnich Rzeczypospolitej." Kombatant w Ameryce. No. 3, 1982: 17. 
government in the streets of American cities (e.g. in New Britain). Much attention to Operation Vistula was dedicated by the Ukrainian press in the U.S. Very critical opinions obviously prevailed, and the deportation campaign itself was referred to as the "illegal and barbarian deportation of the Ukrainians" ("Przegląd Prasy Ukraińskiej." Mikołajczyk Collection) or "drastic and ruthless actions of the communist government of the new Poland" (Karpatiuk 349). Apart from the press, many other papers, including correspondence, reports and memoirs from these events were published. ${ }^{14}$ Such information aroused strong emotions among the members of the Ukrainian immigration group, contributing to spreading and fostering negative stereotypes in social consciousness. Another background for Polish-Ukrainian tensions in the U.S. was also the issue of the unfavorable situation of the Ukrainian minority in the Polish People's Republic, deprived of rights and freedoms. Special appeals and letters aimed at sensitizing the American public opinion on the Ukrainian problem in Poland were also sent to the American government ("UCCA Letter to President Reagan" 316-317). Actions taken up by the Ukrainian diaspora did not, however, bring the expected results. The feedback from the Polish diaspora was also slight by the 1980s. Only the numerous connections between the Ukrainian diaspora and representatives of "Solidarity" in Poland resulted in starting discussions on this issue. On the other hand, the Polish ethnic collectivity in the U.S. was, to a large extent, appalled by the progressing devastation of the Cemetery of the Eaglets in Lviv, being the symbol of "national heroism" and the "lost homeland" for most of the Poles. Therefore, the Polish diaspora took up various initiatives aimed at its protection. ${ }^{15}$ These actions met with negative feedback from the Ukrainian side, perceiving the cemetery as a symbol of Polish domination and dashed hopes for an independent state.

It is worth mentioning that the conflicts between the Polish and Ukrainian diaspora described above were generally characterized by low intensity and fierceness. Even aggression appearing in the ethnic press was of a relatively moderate nature. Nevertheless, the emotional involvement of members of researched groups in what was going on in the Old Continent contributed to maintaining numerous negative stereotypes and prejudices. My research shows that mutual attitudes and stereotypes were brought over from Europe to America by Polish and Ukrainian immigrants. Additionally, in the Cold War period, they were reinforced by the ethnic press. The Ukrainian press often referred to Poles as "occupants," "imperialists," "chauvinists;" the Polish press used such phrases as "Ukrainian nationalism," "enmity towards Poland," "collaboration with Germany during the war," "Ukrainian brutality." It should be noted that the activities not only strengthened mutual

14 The most popular among the members of Ukrainian diaspora were: Walter Dushnyck. "Death and Deviation on the Curzon Line: The Story of the Deportation form Ukraine." The Committee Against Mass Expulsion. The Ukrainian Congress Committee of America. New York 1948 and Bodan Zahajkewycz (ed.), Peremyszl - zachidnij bastion Ukrainy/Peremyshl - The Western Stronghold of Ukraine.

15 And so, for instance, a special Committee for the Lviv Eagles Cemetery Defense was established in 1972 in Hartford, Connecticut; it organized a series of demonstrations in order to propagate the problem of the cemetery among the broader American public opinion. Simultaneously, fundraising actions for its renovation were arranged. See: "Niszczenie Cmentarza Orląt Lwowskich" 17-18. 
prejudice but first and foremost they were used to justify activities of both groups in the U.S. Another factor deepening the intergroup distance in this period were the tensions around interpretation of common history. My research shows that the common history of the two groups is the major factor fueling intergroup distance. There was a clash between groups about perceiving a common history. It means that the same historical events were interpreted differently. What is more, it can be noticed that the memories of common history leads up to the injustice suffered by each ethnic group. This stems from the discrepancies between how both nations interpret certain events in the common history of the two countries. It is quite visible that the vision of history boils down to remembering the wrongs done to one's own ethnic group. In this context the memory of history seems to be one of the most important problems between Poles and Ukrainians. ${ }^{16}$ It could be observed that the past greatly influenced the current behaviors and social interactions. Let the following statements of members of the Polish and Ukrainian diasporas be the indicators of these observations:

Oh but Missus, I need to tell the truth that the Polish group was distanced, and distanced in a negative way from the Ukrainian group at that time. It was because Ukrainians were identified with the Ukrainian Insurgent Army. War emigration that was here experienced many unpleasant contacts, experiences with Ukrainians. And so the relations here travelled overseas, they grew and spread. Ukrainians were treated with some distance, yes. There was no open hostility, but there was hostility on a psychological, emotional and personal level, yes (...).

The Organization of Ukrainian Nationalists and this Ukrainian Insurgent Army, they were fascists organizations. They were atrocious and they committed (...) and because of that, because these crimes were never pointed out, judged (...) the forces of Ukrainian nationalists were not named criminals, as there was never a clear, international trial about it. It was as if you let Germans build monuments of Hitler, Himmler or some others.

There wasn't a good situation, after the World War II there were no good relations. There was the Vistula operation. When the Ukrainians were resettled to the Recovered Territories, then the matter of the border, the shift of the borders, Przemyśl, which belonged to Ukraine became a part of Poland, it also wasn't good, it's such a sensitive matter.

The described conflicts were temporarily intensified or weakened depending on what happened between the groups in Europe. The situation in Europe was also a major factor determining intergroup cooperation.

\section{Intergroup cooperation}

Attempts for dialogue and cooperation, already taken up between the Polish and the Ukrainian diaspora in the U.S. during World War II, were successfully continued in the years 1945-1989, and the intergroup cooperation was intensified by the existence of the common enemy, namely the Soviet Union. This cooperation was

${ }_{16}$ Regarding the event, in the Polish group the context of the event of Volhynia and a matter of evaluating UPA appears; in case of the Ukrainian diaspora the matter of Vistula operation, resettlements and attempts to polonize Ukrainians and shift borders appears. 
often instrumental and the participation in joint campaigns was dictated by their mutual goal to reinforce their position with regard to the USSR. The analysis of the collected documents shows that this cooperation was implemented at two levels: political and cultural-scientific. ${ }^{17}$ The cooperation at the political level manifested itself through belonging to the various coalition organizations, which were focused on anti-Soviet activities. The number of these organizations was quite big, the most important were: Conference of Americans of Central and Eastern European Descent (CACEED), The National Captive Nations Committee (NCNC), Federation of Americans of Central and East European Descent (FACEED), Central European Federation (CEF), Anti-Bolshevik Bloc of Nations (ABN) and Americans from East Central Europe Coordination Committee. ${ }^{18}$ Cooperation taken up within these organizations can be characterized in the best way by the following words of one of Ukrainian World Congress activists $^{19}$ :

We had the Captive Nations organization here. It was a group of active people from Washington DC. On the Polish side there was Professor Brzeziński who diplomatically influenced Polish-Ukrainian relations and he was great at that (...). The Captive Nations Coalition was at that time really functional and Polish-Ukrainian cooperation was supposed to lead to weakening the USSR. And when Poland became an independent country, it also became a ticket to Europe for Ukraine. Poland was the first country which recognized Ukrainian independence. That was the global level of the cooperation.

17 An overall description of these relations from the historical point of view can be found in the works of Anna Mazurkiewicz; see more: „Narody ujarzmione - lobby polityczne czy projekt propagandowy?", 354-392; Uchodźcy polityczni z Europy Środkowo-Wschodniej $w$ amerykańskiej polityce zimnowojennej, 1948-1954 (chapter IV); "Relationship between the Assembly of Captive European Nations and the Free Europe Committee in 1950-1960," 91-130.

18 All the organizations associated a few ethnic groups from East and Central Europe countries, which became territories of Soviet influence. For instance, CACEED, created in 1956 in New York, associated main organizations of the following ethnic communities in the U.S.: Bulgarians, Hungarians, Lithuanians, Czechoslovakians, Estonians, Latvians, Poles, Ukrainians and Romanians. The main goal of this organization was to strengthen their position against the USSR, which was supposed to help liberate them from the Soviets. CACEED expressed it in the following statement: "merit support and encouragement in their struggle for freedom and national independence Interestingly, the Ukrainians did not have their representation in the leading coalition organization, which was the Assembly of Captive European Nation (ACEN). Available archival materials and statements by members of the Ukrainian and Polish diaspora (that was a member of the ACEN) suggest that this situation was connected to the diplomatic activities of the U.S. State Department that throughout the Cold War did not recognize Ukraine diplomatically, treating it similarly to Belarus, Armenia or Georgia, as a traditional part of the Soviet Union, and not a captive nation" ("Przegląd Prasy Ukraińskiej, Grudzień 1961." Mikołajczyk Collection. The Hoover Institute Archive, 1).

19 The Ukrainian World Congress is a general organization established in 1967, representing the interests of the Ukrainian diaspora. It nowadays gathers the members of Ukrainian organizations from over thirty different countries. It was firstly established as the World Congress of Free Ukrainians and only after the collapse of the USSR and the rise of independent Ukrainian state it changed its name to the Ukrainian World Congress. 
Generally speaking, on the level of politics, visible forms of protest were avoided, the activities were limited to propaganda and lobbying, which aimed to gain the support of the public opinion and the American government for the interest of both groups. Already in May 1949, representatives of the Polish and Ukrainian diasporas participated in the "Freedom Rally" organized in Carnegie Hall in New York. During the meeting, gathering in total representatives of twelve ethnic groups from Central and Eastern Europe, a special resolution was passed, obliging these collectivities to struggle with soviet Russia and to peaceful coexistence after liberation ("Ukrainian Delegation at Freedom Rally" 2). Another example of such cooperation was the regular participation of both groups in the "Captive Nations Week" and, conference, organized in 1952 in Milwaukee within the so-called "Freedom Week," where both Polish and Ukrainian group leaders, such as Stanisław Mikołajczyk, Lev Dobriansky and Walter Dushnyck met and debated together ("UCCA Delegates Participate in Anticommunist Conference" 3). Talks have been held at the local level as well, for example the activity of the so-called "Round Table Club" ${ }^{20}$ in New York in the 1960s, and of the Czech-Polish-Ukrainian Society in Chicago in the 1960's and 1970's. ${ }^{21}$ The Polish respondents, on the other hand, pointed out at attempts taken in the 1970's to establish a Polish-Ukrainian committee associated at the KPA. Although the analysis of collected documents does not corroborate the existence of such an institution, it is worth mentioning that the so called Committee on Cooperation with Ethnic Groups was active within the KPA. The activity of the committee was focused on monitoring and maintaining continuous dialogue between the Polish collectivity with various ethnic groups in the U.S., in particular the Jewish and the Ukrainian ones ("Różański Edward Papers"). More evidence of the cooperation of the two groups at the political level included unequivocal support from the American Polonia for the Ukrainian state-building efforts. According to the Polish community activists, Ukraine's independence was crucial for regaining independence by Poland and for the stability and security in Central and Eastern Europe. Expression of this support was evident at various, more or less formal meetings, in statements of ethnic organizations and in the Polish-American press. ${ }^{22}$ At the same time members of the Ukrainian community in the United States expressed strong support for the Polish "Solidarity" movement. This is confirmed by a series of press articles, publications and other documents of Polish and Ukrainian ethnic institutions.

20 This institution, founded by representatives of the Ukrainian diaspora, aimed to organize discussions and seek a political agreement with various ethnic groups, mainly with the Jews, the Czechoslovaks and the Poles. The interviews are available in the co-author's, Anna Fiń's, archive.

21 The analysis of archival documents showed that the Society ceased operations due to the Polish-Ukrainian tensions caused by the issue of the Eastern borders. The information was gathered on a basis of the analysis of Wacław Jędrzejewicz's correspondence with Stanislaw Paprocki, see: „Archiwum Wacława Jędrzejewicza: Korespondencja Wacława Jędrzejewicza ze Stanisławem Paprockim rok 1971." Archives of the Józef Piłsudski Institute in New York, team number 053 , signature 8 .

22 This issue was stressed in the articles of Polonia activists, such as Korboński, Andrew Ehrenkreutz or Zbigniew Brzeziński. 
Wałęsa and this Polish "Solidarność" organization had a very positive impact on the Ukrainians, as it was a turn against communism.

We are not Russia's neighbors. Ukraine, Belarus and Lithuania are our Eastern neighbors" (from the "Program of the Coalition for Polish Independence." The North American Study Center for Polish Affairs, 1977 - “For a Double Understanding..." 237).

Strong, noncommunist Poland needs strong noncommunist Ukraine (Polish Journalist Claude Hrabyk during the Meeting of the Association for Free Ukraine, New York, 1956 "Polish Writer Proposes Polish-Ukrainian Understanding" 4).

Please accept our deep sympathy and support for the gallant struggle of the Polish people led by Solidarity against alien, Moscow-directed Communist rule in Poland. The struggle by Solidarity leaders for genuine democracy has become a source of inspiration among the captive nations in the soviet Russian empire, especially in Ukraine (...). We hasten to assure you that Ukrainians in the United States fully understand the tragedy of the Polish people and stand with them on the same battle lines against the common enemy - Communist and totalitarian Moscow (from the telegram from Lev E. Dobriansky, President of The UCCA to A. Mazewski, President of Polish American Congress - The Ukrainian Quarterly 436).

An important role in shaping Polish-Ukrainian relations in the diaspora was also played by cooperation in the areas of culture and science. It manifested itself mostly through joint participation in various festivals (usually organized under the name of Slavic Culture Week and Slavic Evening), poetry evenings, lectures and conferences. Such actions aimed at popularizing ethnic culture and they were a deliberate way to change negative semantic context of mutual stereotypes. Hence at the beginning of the 1950s, the idea arose to establish the Polish-Ukrainian Society in New York and a permanent Committee of Experts; ${ }^{23}$ in June 1981 a Polish-Ukrainian conference was held in the Ukrainian National Association headquarters in Jersey City; in October 1982 in the Ukrainian Institute in New York; and in March 1984 at the headquarters of the Polish Institute of Science in New York. ${ }^{24}$ Various lectures were also held at the Jozef Pilsudski Institute in New York, in the Kosciuszko Foundation House and in the Consulate General of Poland in New York. The Ukrainian intelligence in exile had particularly strong ties to the Parisian Kultura magazine published by Jerzy Giedroyc. The Ukrainian emigration cooperated with the Parisian Kultura within the scope of such issues as: the borders issue, the history of PolishUkrainian relations, social transformation of the Soviet Ukraine, a presentation of Ukrainian culture and efforts at the "internationalization" of the Ukrainian matter (Giedroyc). All the activities influenced the intensification of contacts between the Poles and the Ukrainians in the diasporas and they enabled contacts with other

23 Information obtained by analysing the correspondence of Ivan L. Rudnycki with Jerzy Giedroyc (Giedroyc) and on the basis of the ethnic press' analysis.

24 Information on organized conferences and lectures has been obtained on the basis of the ethnic press' analysis and on the basis of multimedia documentation: sound recordings from the archives of the Schevchenko Scientific Society and the Polish Institute of Science, see: Schevchenko Scientific Society Archive, K-383, K-384, K-075 and Conference on PolishUkrainian Relations, Oral History Recordings, 19 PIASA Archive, 013 159-162. 
ethnic group, its culture and language and so they increased probability of decreasing social distances. Below I present the statements of my interlocutors referring to the character of Polish-Ukrainian relations in diaspora in scientific and cultural area:

In Chicago, during a Polish Congress conference there was a special Polish-Ukrainian commission and it had memorial on cooperation with Ukrainians. It was about cooperating with Ukrainians. It was an attempt (...). I also know that Mazewski had contacts with the Ukrainian group. In the middle of 1980 we were on a conference in Washington: Mazewski, myself and the director of the Ukrainian organization from Jersey City. He really wanted to make contacts with Poles. You know, people around here weren't really interested so much about that problem, people were friendly, as always, as it was in old Poland, until the 1942 came.

I supported looking for mutual relations, to do something together. But there wasn't much. What we did with Poles was later. There were conferences with The Polish Institute Of Arts and Sciences and others, we had a conference together that was held in the Ukrainian Institute on 79th street, it was a mutual initiative, and its director was Dr. Jarosław Padoch from the Ukrainian Society, and it started in late 1970's.

\section{Summary}

What did then the relations between Polish and Ukrainian immigration groups in the U.S. look like in the period under consideration? What factors impacted their conduct and dynamics? The answers to these questions are brought by the following final conclusions. Firstly, we are dealing here with a kind of projection (translation) of relations and attitudes into emigration conditions. This tendency is clearly visible in the conducted analysis of the institutional level of relations between Polish and Ukrainian emigrants. At this level, two basic forms of intergroup behavior were observed: conflict relations and cooperation. This means that in the time of cold war period relations between Polish and Ukrainians immigrants in U.S. were ambivalent. What is more, there is a clear correlation between what "has happened" between members of the groups in European conditions and intergroup relations in the diaspora. Conflicts and intergroup disagreements which exist in the American society have been transplanted from Europe into the diaspora. This means that they have their roots in the old country and internal American factors had no impact on them. As already mentioned, the conflicts were related to such aspects as: political interests; significant group values and negative attitudes and stereotypes brought over from Europe; cooperative relations, on the other hand, were mostly manifested in the areas of culture and science. Mutual relations have largely been influenced by the development of the situation on the European borderland. Therefore, conflict relations have been intensified or weakened depending on the state of the Polish-Ukrainian relations in Europe and cooperation was much more intensive, when required by the interest of both groups in Europe. In other words, intensity in intergroup cooperation and conflict in the cold war period depended on the interests of the groups in Europe. A more detailed and in-depth analysis has shown, for instance, that the Cold War period was the time of the most intensive cooperation 
between Polish and Ukrainian immigrants. Obviously, the analysis presented herein does not fully explain the entire issue. One shall take into account that relations between immigrant groups are not only of an institutional nature nor are they realized only between institutions. Intergroup relations are of a formal and informal nature; they are also realized between common people in everyday life. In the sphere of migration research this issue has not, however, been well recognized yet and it still keeps "waiting for its time to come."

\section{References:}

Blejwas, Stanisław A. „Polska diaspora w Stanach Zjednoczonych 1939-1989.” [in:] Walaszek, Adam (ed.). Polska diaspora. Kraków: Wydawnictwo Literackie, 2001: 91-109.

Dushnyck, Walter. Death and Devastation on the Curzon Line: The Story of the Deportation form Ukraine. Committee Against Mass Expulsion, Ukrainian Congress Committee of America, 1948.

Fenton, Steve. Etniczność. Transl. Ewa Chojnicka. Warszawa: Wydawnictwo Sic, 2007.

Fin, Anna. "In the space of displaced borderland. A few reflections on the relationships between Polish and Ukrainian immigrants in the United States." Studia Migracyjne - Przeglad Polonijny. No. 1, 2014: 143-161.

"For a Double Understanding between Ukraine and its Neighbors." The Ukrainian Quarterly. No. 3, 1977: 229-235.

Giedroyc, Jerzy. Emigracja ukraińska. Listy 1950-1982. Warszawa: Czytelnik, 2004.

“Immigrants by Country of Birth: 1961-2005." [in:] Yearbook of Immigration Statistics, U.S. Department of Homeland Security, Office of Immigration Statistic. Web. 10 January 2009http:/ / uscis.gov/graphics/shared/statistics/yearbook/index.htm.

Jaroszczynska-Kirchmann, Anna. The Exile Mission. The Polish Political Diaspora and Polish Americans, 1939-1956. Athens, Ohio: Ohio University Press, 2004.

Karpatiuk, Zenon. "Ukrainians in present day Poland." The Ukrainian Quarterly. No. 4, 1977: 348-359.

McDonagh, Edward C. Ethnic Relations in the United States. New York: Appleton Century Crafts, 1953.

Mazurkiewicz, Anna. Uchodźcy polityczni z Europy Środkowo-Wschodniej w amerykańskiej polityce zimnowojennej, 1948-1954. Warszawa: IPN, 2016.

Mazurkiewicz, Anna. "Relationship between the Assembly of Captive European Nations and the Free Europe Committee in 1950-1960." [in:] Kádár Lynn, Katalin (ed.). The Inauguration of "Organized Political Warfare" - The Cold War Organizations Sponsored by the National Committee for a Free Europe / Free Europe Committee. Central European University Press, 2013: 91-130.

Mazurkiewicz, Anna. "'Join, or Die' - The Road to Cooperation Among East European Exiled Political Leaders in the United States, 1949-1954." Polish American Studies. No. 2, 2012: 5-43.

Mazurkiewicz, Anna. „Narody ujarzmione” - lobby polityczne czy projekt propagandowy?” Studia Historica Gedanensia. Vol. 5, 2014: 354-392.

Misiło, Eugeniusz. Akcja "Wisła”. Dokumenty. Warszawa: Archiwum Ukraińskie - Zakład Wydawniczy „Tyrsa”, 1993.

Mucha, Janusz. Stosunki etniczne we współczesnej myśli socjologicznej. Warszawa: Wydawnictwo Naukowe PWN, 2006.

Pawliczko, Lencyk Ann. "Ukrainian Immigration: a study in ethnic survival." [in:] Powers, Mary, and Macisco, John J. (ed.). The Immigration Experience in the United States: Policy Implications. New York: Center for Migration Studies, 1994: 88-110. 
Rokicki, Jarosław. Więź społeczna a zmiana kultur. Studium dynamiki polskiej zbiorowości etnicznej w USA. Wrocław: Zakład Narodowy im. Ossolińskich, 1992.

Stępień, Stanisław. Polacy - Ukraińcy: tradycje wspólnej przeszłości czy ścieranie się racji narodowych? [in:] Bonusiak, Włodzimierz (ed.). Polska - Niemcy - Ukraina w Europie. Rzeszów: Fraza, 1996.

Sztompka, Piotr. Socjologia. Analiza społeczeństwa. Kraków: Wydawnictwo Znak, 2002.

"The Yalta Agreement and the Ukrainian Minority in Poland." The Ukrainian Quarterly. No.3, 1984: 231-240.

Wojakowski, Dariusz. "Stosunki etniczne i wyznaniowe na pograniczu polsko-ukraińskim." Przegląd Polonijny. No. 4, 2014: 81-95.

Wolowyna Oleh. "Immigration and Language of Ukrainians in the United States." The Ukrainian Weekly, 12 October 2003. Web. 20 December 2009. http/ / www.ukweekly.com/old/ archive/2003/410319.shtml?200m_hight=ukrainian+ immigration+waves.

“Ukrainian-Polish Relation. A Turn for the Better?" The Ukrainian Quarterly. No. 4, 1981: 341-351.

Zahajkewycz, Bohdan (ed.). Peremyszl - zachidnij bastion Ukrainy / Peremyshl - The Western Stronghold of Ukraine, Przemyski Komitet Wydawniczy, 1961.

\section{Archive Sources}

"Archiwum Wacława Jędrzejewicza: Korespondencja Wacława Jędrzejewicza ze Stanisławem Paprockim rok 1971." Józef Piłsudski Insititute of America Archive. No 053, folder 8.

"Conference on Polish-Ukrainian Relations." Oral History Recordings, 19 PIASA Archive, 013 159-162.

"Political Currents among Ukrainian Americans." Polish Embassy in the U.S., PIASA Archive, Box 12, folder 13.

"Przegląd Prasy Ukraińskiej." Polish Embassy in the U.S., PIASA Archive, Box 12, folder 17.

"Przegląd Prasy Ukraińskiej." Stanisław Mikołajczyk Collection. Hoover Institute Archive, Box 116, folder 2, no 68.

“Różański Edward Papers." IHRC Archive, Collection 144, Team number 30, folder 3.

Schevchenko Scientific Society Archive. Recordings: K-383, K-384, K-075.

"Walter Dushnyck, Recognition of Ukrainian in the U.S. Census, The Ukrainian Congress Committee of America, 1960." Immigration History Research Center Archive, Collection no 10.

“Walter Dushnyck, Ukrainian Political Situation Today.” IHRC Archive, Collection no 7.

\section{Press Sources}

"Declaration of the Ukrainian Congress Committee of America on the Matter of UkrainianPolish Relations." The Ukrainian Bulletin, 1-15 June 1957: 2.

Mękarska, Józefa. “Wędrówka po ziemiach wschodnich Rzeczypospolitej.” Kombatant w Ameryce. No. 2, 1982: 15-18; No. 3, 1982: 17-19; No. 1, 1983: 18-10; No. 4, 1983: 16-18.

“Niszczenie Cmentarza Orląt Lwowskich.” Kombatant w Ameryce. No. 2, 1972: 17-18.

"Polish-Ukrainian Relations Today." The Ukrainian Quarterly. No. 2, 1948: 106-108.

"Polish Writer Proposes Polish-Ukrainian Understanding." The Ukrainian Bulletin, 1 May 1956: 4.

"UCCA Letter to President Reagan." The Ukrainian Quarterly. No. 3, 1984: 316-317.

"UCCA Scores Imperialics deings of American Poles." The Ukrainian Bulletin, 1-15 November 1960: 3.

“Ukrainian Delegation at Freedom Rally." The Ukrainian Bulletin, 15 May 1949: 2. 